\title{
Oil Extraction from Rice Bran with Various Solvents and Concentration of Crude Extract to Antioxidant Activity
}

\author{
Arief Suryadinata \\ Jurusan Kimia, Fakultas Sains dan Teknologi, Universitas Islam Negeri Maulana Malik Ibrahm Malang
}

\begin{abstract}
Rice bran contains components such as oryzanol antioxidants, tocopherols, tocotrienols, phytosterols, polyphenols, and squalene. Oryzanol is a very powerful antioxidant and oryzanol is only found in rice bran oil. This research aims to know the antioxidant activity of the extract chloroform:methanol in the bran and find the endurance of antioxidant against a wide variety of $\mathrm{pH}$ and temperature. The method used is descriptive research through experimental tests in the laboratory. Samples taken from the side of rice mills in the form of bran and then macerated with chloroform: methanol. After that tested the antioxidant activity of the compounds made by the method of DPPH with various concentration 10, 20, 30, 40 and $50 \mathrm{ppm}$. Furthermore, the endurance test of antioxidant compounds at various $\mathrm{pH}$ and temperature using the best concentration of antioxidant compounds. Based on the results, rice bran oil extract concentration of $50 \mathrm{ppm}$ has antioxidant activity of $4.69 \%$. Average yield the highest antioxidant activity shown in heating conditions with a temperature of $30 \mathrm{oC}$ for 30 minutes is equal to $32.25 \%$. As well as the highest antioxidant activity was also shown at $\mathrm{pH} 5$ in the amount of $25.1 \%$.
\end{abstract}

Keywords: DPPH, Oryzanol, Rice bran

\begin{abstract}
Abstrak
Bekatul mengandung komponen-komponen antioksidan seperti oryzanol, tokoferol, tokotrienol, phytosterol, polifenol, dan squalene. Oryzanol merupakan antioksidan yang sangat kuat dan hanya ditemukan pada minyak bekatul. Penelitian ini bertujuan untuk mengatahui aktivitas antioksidan ekstrak kloroform: metanol dalam bekatul dan mengetahui ketahanan senyawa antioksidan ekstrak kloroform: metanol bekatul terhadap berbagai variasi $\mathrm{pH}$ dan suhu. Metode penelitian yang digunakan adalah penelitian secara deskriptif melalui pengujian eksperimental di laboratorium. Sampel diambil dari hasil samping penggilingan padi yang berbentuk bekatul kemudian dimaserasi dengan pelarut kloroform : metanol. Setelah itu dilakukan uji aktivitas senyawa antioksidan dilakukan dengan metode DPPH dengan variasi konsentrasi 10, 20, 30, 40 dan 50 ppm. Selanjutnya dilakukan uji ketahanan senyawa antioksidan pada berbagai $\mathrm{pH}$ dan suhu menggunakan konsentrasi terbaik sebagai senyawa antioksidan. Berdasarkan hasil penelitian didapatkan Ekstrak minyak bekatul konsentrasi $50 \mathrm{ppm}$ memiliki aktivitas antioksidan sebesar 4,69\%. Hasil rata-rata aktivitas antioksidan paling tinggi ditunjukkan pada kondisi pemanasan dengan suhu $30^{\circ} \mathrm{C}$ selama 30 menit yaitu sebesar $32,25 \%$. Serta aktivitas antioksidan paling tinggi juga ditunjukkan pada kondisi pH 5 yaitu sebesar 25,1\%.
\end{abstract}

Kata kunci: Bekatul, DPPH, Oryzanol

\section{PENDAHULUAN}

Bekatul merupakan produk samping penggilingan gabah menjadi beras. Penggilingan satu ton gabah menghasilkan bekatul sebanyak 60-80 kg (Goffman et al., 2003). Cahyanine (2008) menyebutkan bahwa dalam proses penggilingan padi menjadi beras giling diperoleh hasil samping sebagai berikut: (1) sekam (15$20 \%$ ), yaitu bagian pembungkus atau kulit luar; (2) bekatul (8-12\%), yang merupakan kulit ari, dihasilkan dari proses penyosohan dan (3) menir (3\%), merupakan bagian beras yang hancur.
Bekatul mengandung komponenkomponen antioksidan seperti oryzanol, tokoferol, tokotrienol, phytosterol, polifenol, dan squalene (Goffman et al, 2003; Ozgul and Türkay, 1993). Menurut hasil penelitian dari Balai Besar Penelitian dan Pengembangan Pascapanen Pertanian (2007), minyak bekatul mengandung antioksidan alami tokoferol, tokotrienol dan oryzanol yang bermanfaat melawan radikal bebas dalam tubuh terutama sel kanker, serta membantu menurunkan kadar kolesterol dalam darah. Orizanol merupakan antioksidan yang sangat kuat 
dan hanya ditemukan pada minyak bekatul. Damayanthi (2003) menjelaskan tentang terdapatnya komponen-komponen bioaktif pada bekatul yaitu zat yang didalam tubuh bekerja di luar fungsi karbohidrat, lemak, protein dan mineral. Komponen tersebut diantaranya adalah tokoferol (Vitamin E), tokotrienol, oryzanol dan asam pangamat.

Antioksidan bekerja dengan cara mendonorkan satu elektronnya kepada senyawa yang bersifat oksidan sehingga aktivitas senyawa oksidan tersebut bisa dihambat. Keseimbangan oksidan dan antioksidan sangat penting karena berkaitan dengan berfungsinya sistem imunitas tubuh. Kondisi tersebut terutama untuk menjaga integritas dan berfungsinya membran lipid, protein sel dan asam nukleat serta mengontrol transduksi signal dan ekspresi gen dalam sel imun (Meydani et al., 1995).

Ekstraksi senyawa antioksidan dalam bekatul dengan menggunakan perbandingan pelarut non polar dan polar. Terdapat banyak senyawa antioksidan dalam minyak bekatul sehingga perbedaan pelarut akan mempengaruhi hasil ekstraksi. Pelarut yang dapat digunakan adalah kloroform : metanol dengan metode maserasi yang bertujuan untuk mencegah rusaknya kandungan antioksidan dan mendapatkan minyak bekatul kasar dalam kadar maksimal dengan kualitas yang baik. Azizah (2008), menyatakan bahwa kloroform dan metanol dengan perbandingan 3:2 untuk mengekstrak minyak bekatul menghasilkan rendemen minyak sebesar $16,5 \%$ dan terdapat senyawa antioksidan oryzanol.

Sebagai metode pengujian antioksidan pada pangan digunakan larutan DPPH sebagai indikator dimana semakin berkurangnya warna DPPH menandakan presentase aktivitas penangkapan radikal bebas. Keuntungan menggunakan metode DPPH adalah metode yang sederhana, mudah dan menggunakan sampel dalam jumlah yang sedikit. Selain menggunakan
DPPH dalam menentukan aktivitas antioksidan, digunakan larutan BHT sebagai pembanding. Penggunaan metode DPPH ini sudah banyak digunakan untuk mengidentifikasi senyawa antioksidan contohnya penelitian yang dilakukan oleh Hayati (2009) menggunakan metode DPPH dalam menentukan aktivitas antioksidan dalam buah pepino kemudian Ping (2012) juga melaporkan tentang penggunaan metode DPPH dalam menentukan komponen antioksidan dalam buah tunjuk langit (sky fruit).

Tujuan dari penelitian ini yaitu mengatahui aktivitas antioksidan ekstrak kloroform: metanol dalam bekatul dan mengetahui ketahanan senyawa antioksidan ekstrak kloroform: metanol bekatul terhadap berbagai variasi $\mathrm{pH}$ dan suhu.

\section{METODE PENELITIAN}

\section{Alat dan Bahan}

Alat-alat yang digunakan dalam penelitian ini adalah beaker glass $500 \mathrm{~mL}$ dan $1000 \mathrm{~mL}$, pipet ukur $1 \mathrm{~mL}, 5 \mathrm{~mL}$ dan $10 \mathrm{~mL}$, gelas ukur $25 \mathrm{~mL}, 100 \mathrm{~mL}, 500 \mathrm{~mL}$, erlenmeyer $250 \mathrm{~mL}, 500 \mathrm{~mL}$ dan $1000 \mathrm{~mL}$, gelas arloji, corong gelas, labu takar, bola hisap, spatula, pengayak, rotary evaporator vacum, kuvet, pipet tetes, aluminium foil, neraca analitik, pemanas air, seperangkat ekstraktor maserasi, spektrofotometer UV$\mathrm{Vis}$, magnetic stirrer, tabung reaksi, instrumen FT-IR.

Bahan yang digunakan adalah sebagai berikut: bekatul beras, larutan kloroform p.a, larutan metanol p.a, $\mathrm{KOH}$ $12 \%$, gas nitrogen, $\mathrm{H}_{2} \mathrm{SO}_{4} 1 \mathrm{M}, \mathrm{H}_{2} \mathrm{SO}_{4} 1 \%$, $\mathrm{MgSO}_{4}$ anhidrous larutan DPPH, larutan BHT, asam askorbat, kertas saring dan aquades.

\section{Tahapan Penelitian}

Metode penelitian yang digunakan adalah penelitian secara deskriptif melalui pengujian eksperimental di laboratorium. Sampel diambil dari hasil samping penggilingan padi yang berbentuk bekatul 
kemudian dimaserasi dengan pelarut kloroform : metanol. Setelah itu dilakukan uji aktivitas senyawa antioksidan dilakukan dengan metode DPPH dengan variasi konsentrasi 10, 20, 30, 40 dan 50 ppm. Selanjutnya dilakukan uji ketahanan senyawa antioksidan pada berbagai $\mathrm{pH}$ dan suhu menggunakan konsentrasi terbaik sebagai senyawa antioksidan.

Bekatul dipanaskan dengan cara pengukusan selama 60 menit kemudian dikeringanginkan dan diayak dengan ukuran 60 mesh. Sebanyak 60 gram bekatul direndam menggunakan $300 \mathrm{~mL}$ kloroform : metanol (3:2) selama 24 jam kemudian dishaker selama 3 jam dan dilanjutkan remaserasi dengan cara maserasi berulang terhadap ampas dari hasil maserasi pertama menggunakan cara dan pelarut yang sama. Filtrat yang diperoleh, dipekatkan dengan rotary evaporator sampai ekstrak tidak menetes lagi, sehingga diperoleh ekstrak pekat. Ekstrak pekat kemudian dialiri dengan gas $\mathrm{N}_{2}$ untuk menghilangkan pelarut yang masih tersisa pada filtrat.

Penentuan panjang gelombang maksimum dilakukan dengan cara etanol sebanyak 6,75 $\mathrm{mL}$ dimasukkan ke dalam kuvet, kemudian ditambahkan larutan DPPH 0,5 mM sebanyak 2,25 $\mathrm{mL}$ dan dimasukkan dalam kuvet hingga penuh. Selanjutnya dicari $\lambda_{\text {maks }}$ larutan pada rentangan panjang gelombang 500-600.

Penentuan waktu kestabilan antioksidan dilakukan dengan menyiapkan larutan ekstrak 30 ppm sebanyak $250 \mathrm{~mL}$, kemudian diambil sebanyak $6,75 \mathrm{~mL}$ dan dimasukkan dalam tabung reaksi. Ditambahkan 0,5 mM larutan DPPH sebanyak 2,25 mL, kemudian dicari waktu kestabilan tanpa inkubasi dan setelah inkubasi pada suhu $37{ }^{\circ} \mathrm{C}$ pada rentangan waktu $5-100$ menit dengan interval 5 menit. Sampel diukur menggunakan spektrofotometer $\mathrm{Uv}-\mathrm{V}$ is pada $\lambda_{\text {maks }}$ yang telah diketahui pada tahap sebelumnya.
Aktivitas antioksidan diukur dengan menggunakan Sampel ekstrak kasar dilarutkan dalam kloroform : metanol dengan konsentrasi 10, 20, 30, 40 dan 50 ppm. Kemudian disiapkan tiga tabung reaksi untuk masing-masing konsentrasi, kemudian tiap-tiap tabung reaksi untuk masing-masing konsentrasi diisi dengan 6,75 mL ekstrak dan ditambahkan DPPH $0,5 \mathrm{mM}$ sebanyak 2,25 $\mathrm{mL}$ (perbandingan larutan DPPH : ekstrak yang dilarutkan dengan konsentrasi tertentu 1:3). Setelah itu larutan ditutup dengan tisue dan diinkubasi dengan suhu $37{ }^{\circ} \mathrm{C}$ pada waktu kestabilan yang diperoleh pada proses sebelumnya, kemudian dimasukkan ke dalam kuvet hingga penuh dan diukur absorbansinya menggunakan spektrofotometer UV-Vis pada $\lambda_{\text {maks }}$ yang telah didapatkan sebelumnya. Data absorbansinya yang diperoleh dari tiap konsentrasi masingmasing ekstrak dihitung nilai persen (\%) aktivitas antioksidannya.

Uji ketahanan aktivitas antioksidan terhadap panas menggunakan sampel ekstrak kasar dilarutkan dalam propilen glikol dengan konsentrasi 50 ppm sebanyak $1 \mathrm{~mL}$ ditempatkan pada tabung reaksi dan dipansakan pada suhu 100 oC, $125 \mathrm{C}, 150$ $\mathrm{C}$ dan $175 \mathrm{C}$ masing-masing selama 30,60 , 90 dan 120 menit dalam Oil bath. Aktivitas antioksidan diukur dengan metode DPPH.

Uji ketahanan aktivitas antioksidan terhadap $\mathrm{pH}$ menggunakan sampel ekstrak kasar dilarutkan dalam $10 \mathrm{ml}$ minyak kedelai dengan konsentrasi 50 ppm ditempatkan pada botol gelas gelap dan tertutup. Selanjutnya dibuat emulsi (o/w) 10 $\%$ dengan buffer phosphat $\mathrm{pH} 3,4,5,6$ dan 7. Sampel tersebut dioksidasi pada suhu 37 C selama 12 hari pada inkubator. Aktivitas antioksidan diukur menggunakan metode DPPH.

Secara ringkas, penjabaran diatas dapat dituliskan sebagai berikut :

1. Preparasi sampel 
2. Ekstraksi komponen aktif

3 Uji aktivitas senyawa antioksidan

4. Uji ketahanan antioksidan pada berbagai $\mathrm{pH}$ dan suhu

\section{HASIL DAN PEMBAHASAN}

Hasil pengukuran pada ekstrak bekatul dengan kloroform:metanol didapatkan panjang gelombang maksimum larutan DPPH 0,2 mM sebesar 516,9 nm dengan nilai absorbansi 0,736 dengan waktu kestabilan antara 40-70 menit.

Ekstrak minyak bekatul konsentrasi 50 ppm memiliki aktivitas antioksidan sebesar 4,69\%. Secara kualitatif aktivitas antioksidan sampel dapat dilihat dari perubahan warnanya dari ungu menjadi kuning. Pada penelitian ini hasil pengukuran masing-masing ekstrak ketika ditambahkan larutan DPPH tidak mengalami perubahan warna dari ungu menjadi kuning, melainkan hanya terjadi pemudaran warna dari ungu menjadi pink keunguan pada konsentrasi $50 \mathrm{mg} / \mathrm{L}$. Hal ini menunjukkan bahwa ekstrak minyak Bekatul beras tergolong dalam senyawa antioksidan yang lemah jika dibandingkan dengan antioksidan pembanding yaitu vitamin $\mathrm{C}$ dan BHT.

Perubahan warna dari ungu menjadi kuning pada sampel vitamin $\mathrm{C}$ dan BHT dikarenakan radikal DPPH memiliki warna ungu dan berubah menjadi kuning setelah radikal DPPH berpasangan (Yuliani, 2011). Vitamin $\mathrm{C}$ mengalami perubahan warna pada konsentrasi $10 \mathrm{ppm}$ dan BHT juga mengalami perubahan warna pada konsentrasi $10 \mathrm{ppm}$. Pengurangan intensitas warna mengindikasikan peningkatan kemampuan antioksidan dalam menangkap radikal bebas (Prakash, 2001). Perubahan warna yang terjadi pada vitamin $\mathrm{C}$ dan BHT menunjukkan tingginya kemampuan kedua antioksidan tersebut dalam menangkap radikal bebas DPPH.

\begin{tabular}{ccccc} 
Tabel 1. Hasil & \multicolumn{2}{c}{ Persentase } & Aktivitas \\
& Antioksidan & \\
\hline & & \multicolumn{2}{c}{$\%$ Aktivitas antioksidan } \\
\cline { 3 - 5 } No. & $\begin{array}{c}\text { Konsentrasi } \\
\text { Sampel } \\
\end{array}$ & $\begin{array}{c}\text { Vitamin } \\
\text { (ppm) }\end{array}$ & BHT & $\begin{array}{c}\text { Ekstrak } \\
\text { Kloroform } \\
\text { : Metanol }\end{array}$ \\
\hline 1. & 10 & 95,55 & 50,15 & 1,35 \\
2. & 20 & 96,15 & 61,65 & 1,48 \\
3. & 30 & 96,23 & 76,77 & 2,59 \\
4. & 40 & 96,29 & 82,39 & 3,41 \\
5. & 50 & 95,91 & 85,63 & 4,69 \\
\hline
\end{tabular}

Berdasarkan mekanisme kerjanya, Vitamin $\mathrm{C}$ atau asam askorbat termasuk dalam antioksidan sekunder. Antioksidan ini berfungsi sebagai sistem pertahanan preventif yaitu dengan cara memotong atau memutuskan reaksi oksidasi berantai dari radikal bebas. Asam askorbat memberikan 2 atom $\mathrm{H}$ kepada senyawa radikal nitrogen pada DPPH. Meskipun telah mendonorkan atom H-nya, asam askorbat tetap stabil dengan mengubah dirinya menjadi dehidroL-asam askorbat. asam askorbat mampu mereduksi radikal bebas DPPH dengan mendonorkan 1 atom hidrogen sehingga menghasilkan produk radikal L-asam askorbat. Radikal L-asam askorbat akan segera berubah menjadi radikal L-askorbil, radikal-radikal yang terbentuk bersifat stabil. Hal tersebut disebabkan kemampuan radikal untuk menstabilkan diri dengan cara beresonansi (Arindah, 2010).

Sedangkan senyawa antioksidan

BHT (Butylated hydroxytoluene) merupakan antioksidan sintetik yang juga memiliki kemampuan untuk meredam radikal bebas. Antioksidan BHT merupakan senyawa aromatik yang memiliki satu gugus hidroksil. Antioksidan BHT ini mendonorkan 1 atom hidrogennya pada gugus hidroksil kepada DPPH sehingga radikal DPPH tereduksi menjadi DPPH-H. BHT yang menjadi radikal fenoksi lebih stabil. Kestabilan radikal fenoksi ini disebabkan karena radikal fenoksi dapat mendelokasikan elektronnya (Husnah, 2004). 
Tabel 2. Aktivitas antioksidan akibat pengaruh suhu dan waktu pemanasan

\begin{tabular}{lllll}
\hline $\begin{array}{l}\text { Menit } \\
\text { Ke }\end{array}$ & \multicolumn{4}{c}{ Aktivitas antioksidan (\%) } \\
\hline & $30^{\circ} \mathrm{C}$ & $60{ }^{\circ} \mathrm{C}$ & $100^{\circ} \mathrm{C}$ & $125^{\circ} \mathrm{C}$ \\
30 & 32,25 & 26,7 & 12,6 & 7,36 \\
60 & 28,3 & 23,3 & 12,75 & 3,005 \\
90 & 28,8 & 20 & 10 & 1,55 \\
120 & 31,6 & 23,7 & 10 & 1,55 \\
\hline
\end{tabular}

Hasil rata-rata aktivitas antioksidan akibat pengaruh suhu dan waktu pemanasan paling tinggi ditunjukkan pada kondisi pemanasan dengan suhu $30^{\circ} \mathrm{C}$ selama 30 menit. Pada kondisi ini didapatkan nilai aktivitas antioksidan sebesar $32,25 \%$. Pada suhu $30^{\circ} \mathrm{C}$ setelah pemanasan setelah 120 menit kadar aktivitas antioksidan hanya mengalami penurunan sebesar 2\%. Hal ini menunjukkan bahwa pada pemanasan suhu $30^{\circ} \mathrm{C}$, lama waktu pemanasan tidak berpengaruh banyak pada daya aktivitas antioksidan. Aktivitas antioksidan paling rendah ditunjukkan pada pemanasan suhu $125^{\circ} \mathrm{C}$ selama 90 dan 120 menit, pada kondisi ini didapatkan nilai aktivitas antioksidan sebesar $1,55 \%$. Hal ini jika dibandingkan dengan kadar maksimum aktivitas antioksidan pada suhu $30^{\circ} \mathrm{C}$ maka pada kondisi suhu $125^{\circ} \mathrm{C}$ telah terjadi penurunan aktivitas antioksidan sebesar $95,2 \%$.

Hasil uji aktivitas antioksidan menunjukkan bahwa lama waktu pemanasan pada suhu pemanasan yang sama tidak memberikan hasil nilai aktivitas antioksidan yang berbeda secara nyata. Pada kondisi suhu $30^{\circ} \mathrm{C}$ terjadi penurunan aktivitas antioksidan sebesar $2 \%$, pada suhu $60^{\circ} \mathrm{C}$ terjadi penurunan sebesar $11,2 \%$ dan pada suhu $100^{\circ} \mathrm{C}$ terjadi penurunan aktivitas antioksidan sebesar 20,6 \% sedangkan pada suhu $125^{\circ} \mathrm{C}$ terjadi penurunan secara drastis yaitu sebesar $78,9 \%$.

Peningkatan suhu pemanasan memberikan pengaruh yang cukup besar terhadap aktivitas antioksidan pada kondisi waktu pemanasan yang sama. Aktivitas antioksidan terlihat memiliki tren yang terus menurun seiring dengan peningkatan suhu pemanasan. Pada keadaan pemanasan suhu $100^{\circ} \mathrm{C}$ menyebabkan terjadi penurunan aktivitas antioksidan dengan interval sebesar $55-68 \%$ demikian juga pada kondisi peningkatan suhu hingga $125 \%$ telah terjadi penurunan aktivitas antioksidan hingga 95\%. Pada kondisi pemanasan suhu $60^{\circ} \mathrm{C}$ terjadi penurunan aktivitas antioksidan dengan interval 17$30 \%$.

Hasil analisis ketahanan panas aktivitas antioksidan dalam ekstrak minyak bekatul dapat disimpulkan bahwa jenis antioksidan tersebut relatif tidak tahan terhadap pemanasan. Pemanasan pada suhu $125^{\circ} \mathrm{C}$ selama 2 jam dapat menurunkan aktivitas antioksidan sebesar 95,2\%. Jika dibandingkan dengan hasil penelitian Hamama dan Nawar yang diacu Yen dan Duh (1993) bahwa aktivitas antioksidan BHA mengalami penurunan sebesar $50 \%$ setelah dipanaskan pada suhu $185^{\circ} \mathrm{C}$ selama 45 menit maka ketahanan panas antioksidan ekstrak minyak bekatul dianggap masih kurang baik. Merujuk pada kondisi tersebut maka dapat disimpulkan bahwa antioksidan ekstrak bekatul tidak stabil terhadap pemanasan.

Aktivitas antioksidan paling tinggi ditunjukkan pada kondisi $\mathrm{pH} 5$ yaitu sebesar $25,1 \%$ sedangkan nilai aktivitas antioksidan paling rendah terjadi pada kondisi $\mathrm{pH} 3$ sebesar 2,15\%. Nilai aktivitas antioksidan ini relatif stabil hingga $\mathrm{pH} 7$, pada keadaan ini terjadi penurunan aktivitas antioksidan yang relatif kecil yaitu sebesar $17,3 \%$. Sedangkan pada kondisi $\mathrm{pH} 3$ terjadi penurunan nilai aktivitas antioksidan yang signifikan yaitu sebesar $91,4 \%$. 
Tabel 3 Aktivitas antioksidan terhadap $\mathrm{pH}$

\begin{tabular}{ccccc}
\hline \multicolumn{5}{c}{ Aktivitas antioksidan pada $\mathrm{pH}$} \\
\hline 3 & 4 & 5 & 6 & 7 \\
\hline $2,15 \%$ & $13.7 \%$ & $25,1 \%$ & $19,6 \%$ & $20,75 \%$ \\
\hline
\end{tabular}

Antioksidan kelompok senyawa fenolik berperan sebagai donor hidrogen yang bertugas untuk menstabilkan senyawa radikal bebas (Shahidi dan Naczk, 1995). Pada kondisi $\mathrm{pH}$ yang rendah densitas ion hidrogen dalam medium meningkat sehingga menekan pelepasan ion hidrogen dari senyawa fenolik. Pada kondisi $\mathrm{pH}$ rendah memiliki konsentrasi ion fosfat yang tinggi, pada keadaan ini asam fosfat memiliki fungsi sebagai pengkelat logam yang dapat menginisiasi reaksi oksidasi (Kikugawa et al, 1990; Chen et al, 1996). Hal ini menyebabkan tingkat oksidasi pada $\mathrm{pH}$ rendah dapat ditekan. Hal ini sesuai dengan hasil penelitian Huang et al (1996) yang meyatakan bahwa tingkat oksidasi emulsi dengan buffer fosfat lebih rendah dibandingkan dengan emulsi tanpa buffer pada kondisi $\mathrm{pH}$ yang sama.

Dengan meningkatnya $\mathrm{pH}$ maka konsentrasi ion hidrogen dalam medium menurun sehingga akan terjadi pelepasan ion hidrogen dari senyawa fenolik (antioksidan). Dari analisis ketahanan aktivitas antioksidan dalam ekstrak minyak bekatul terhadap $\mathrm{pH}$ dapat disimpulkan bahwa jenis antioksidan tersebut relatif tidak tahan terhadap $\mathrm{pH}$ yang asam sedangkan pada $\mathrm{pH}$ netral antioksidan tersebut relatif stabil.

\section{KESIMPULAN}

Panjang gelombang maksimum larutan DPPH 0,2 mM sebesar 516,9 nm dengan nilai absorbansi 0,736. Waktu kestabilan ekstrak kloroform:metanol adalah 40-70 menit. Ekstrak minyak Bekatul beras memiliki aktivitas antioksidan walaupun memiliki tingkat antioksidan yang lemah. Ekstrak minyak bekatul konsentrasi 50 ppm memiliki aktivitas antioksidan sebesar 4,69\%.
Pemanasan pada suhu $125^{\circ} \mathrm{C}$ selama 2 jam dapat menurunkan aktivitas antioksidan sebesar 95,2\%. Merujuk pada kondisi tersebut maka dapat disimpulkan bahwa antioksidan ekstrak bekatul tidak stabil terhadap pemanasan. Pada kondisi $\mathrm{pH}$ 3 terjadi penurunan nilai aktivitas antioksidan yang signifikan yaitu sebesar $91,4 \%$. Antioksidan ekstrak minyak bekatul dapat disimpulkan bahwa relatif tidak tahan terhadap $\mathrm{pH}$ yang asam sedangkan pada $\mathrm{pH}$ netral antioksidan tersebut relatif stabil.

\section{DAFTAR PUSTAKA}

Balai Besar Penelitian dan Pengembangan Pascapanen Pertanian. 2007. Mengolah Dedak menjadi Minyak ( Rice Bran Oil ). Warta Penelitian dan Pengembangan Pertanian Vol. 29 No. 4.

Cahyaninne, et al. 2008. Fraksi Kaya Tokoferol dari Bekatul Beras ( Oryza sativa) dengan Tekhnik Rekristalisasi Pelarut Suhu Rendah. Jurnal Tekhnologi Pertanian Vol. 9 No. 3 165-172.

Damayanthi E, Tjing LT dan Arbianto L. 2007. Rice Bran. Depok: Panebar Swadaya. Hal. 28.

Gordon, M.H 1990. The Mechanism of Antioxidants Action in Vitro. Di dalam: B.J.F. Hudson, editor. Food Antioxidants. London: Elsivier Applied Science.

Huang , S.W., E.N. Frankel, K. Schwarz, and J.B. German. 1996. Effect of $\mathrm{pH}$ on Antioxidant Activity of Alfa Tocophenrol and Trolox in Oil-inWater Emulsions. J. Agric. Food Chem. 44: 2951-2956.

Kikugawa, Ak. A. Kurechi, T. Kunugi. 1990. Chemistry and Implication of Degradation of Phenolic Antioxidant. Di dalam : Hudson B.J.F. (ed). Food Antioxidant. Hal 65-98. Elsevier Applied Science, New York. 
Molyneux, P.. 2003. The Use of The Stable

Free

Radical

Diphenylpicrylhydrazyl (DPPH), for

Estimating Antioxidant Activity.

Science and Technology, XXVI (2) : 211-219

Prakash, A., Freg, R and Eugene, M. 2001. Antioxidant Activity. Medallion Laboratories-Analytical Progress. Volume 19. Number 2

Schwarz, K. 2001. Investigation of Plant Extracts for the Protection of Processed Foods Againts Lipid Oxidation. Comparison of Antioxidant Assays Based on Radical Scavenging, Lipid
Oxidation and Analysis of the Principal Antioxidant Compunds. Eur. Food Res Technol. 212(3) : 319-328.

Shu Jing Wu dan Lean Teik Ng. 2007. Antioxidant and Free Radical Scavenging Activities of Wilod Bitter Melon (Momordica charantia Linn. Var. abbreviata Ser.) in Taiwan. Taiwan: Universityu of Pharmacy and Technology. Pages 323-330.

Yen, G.C. and P.D.Duh. 1993. Antioxidative Properties of Methanolic Extracts from Peanut Hulls. JA.OCS. 70:598-601 